\title{
Assess the Knowledge and Attitude of Barbers Toward HIV / AIDS infection
}

\author{
Afsaneh Karami, Ahad Miandari, Alireza Shoghli and Goudarz Koli Farhood \\ Assistant Professor, Zanjan University of Medical Sciences, Zanjan, Iran.
}

DOI: http://dx.doi.org/10.13005/bbra/1901

(Received: 09 September 2015; accepted: 30 October 2015)

\begin{abstract}
AIDS, including emerging disease that has no cure has been discovered for it and primary prevention is the only way to avoid it, Barbers are those who use sharp tools as a means for work and contamination of these devices is effective at infecting others. This study aimed to determine the knowledge, attitude and practice of the male and female barber carried about AIDS prevention in Zavjan. Methods: In this cross - sectional study involving questionnaires to examine the knowledge and attitude about AIDS among male and female barbers in Zanjan city who were selected randomly distributed the necessary information. Statistical analysis was then extracted information and considered. In this study we evaluated information of 375 questionnaires, of which among them 4.42 percent were male and 6.57 percent were female barbers. The average age of men is $34.85 \pm 47$ years, the average age of women is $34.25 \pm 9.36$ years and the mean age of the patients studied $36.9 \pm 25.34$ years.4.26 of low level of knowledge, $3.28 \%$ of moderate of knowledge and 4.45 percent had good knowledge. In attitude part 1.26 percent positive attitude and 1.62 percent acceptable attitude, and 7.11 percent had moderate attitude, knowledge and attitudes have positive relationship between gender, level of education and years of education. The results of this study showed that knowledge of the subjects is at relatively low levels, and among people with low literacy and the education and men and those with a history of less do not have AIDS majority of people in an appropriate level of awareness the propose future studies will also be considered in addition to the knowledge and attitude of the people.
\end{abstract}

Keywords: Acquired Immune Deficiency Virus, knowledge and attitudes, beauticians, Zanjan

AIDS, including emerging disease that has no cure has been discovered for it and the only way to avoid it is primary prevention ${ }^{1-2}$ when the first official report on AIDS was published 40 years ago no one knew the most devastating epidemics in human history born ${ }^{3}$.The sudden emergence of AIDS, hope the medical world who believed they could eradicate all infectious diseases into desperation ${ }^{4}$ medical community his

* To whom all correspondence should be addressed. greatest triumph in the past half century the eradication of smallpox and AIDS knows no doubt the most catastrophic defeat the scourge of human society since World War, AIDS, we are faced with a disaster that destroyed its destructive effects millions of people hope and opportunity to develop and improve the quality of life wasted ${ }^{5}$.

The incidence of the disease among US homosexuals in America 1981, it seemed that social group and in particular AIDS and certain geographical area is limited. But the emergence of a new model of disease transmission through sexual contact and intravenous drug abuse to drug 
showed that AIDS was a global problem and not limited to a country or a particular group ${ }^{6}$.AIDS is undoubtedly the most important emerging infectious disease in the late twentieth century forms So until about three decades ago, there was even one case of it, but in less than 20 years has affected more than 70 million people affected The condition of the main obstacles to the development of communities and society is more active and productive population ${ }^{7}$. Since currently there is no vaccine or treatment is not possible, prevention is the only way to deal with it and the most important way to prevent it is training. The first step in training is public awareness and the attitude and belief that ultimately lead to changes in behavior, this training is successful when is based on the facts available the society. Methods to achieve this reality,is collecting information from the population in the society, which leads to the selection of the most appropriate way to teach ${ }^{8-9}$ in Iran and other countries, several studies have been conducted to assess public awareness of studies show a wide range of knowledge in different populations, so researchers said aware of the population of 6 to 80 percent $^{10-11}$.

Barbers, include the owners that use sharp tools as a means in work and contamination of these devices is effective at infecting others according to their 1000 annual studies of occupational exposure are infected with the ${ }^{12}$. Therefore, it is necessary for the study to determine the knowledge, attitude of male and female barbers

Table 1. Frequency response questions on assessing the level of awareness among the studied people

\begin{tabular}{|c|c|c|c|c|c|}
\hline \multirow[t]{2}{*}{ Rows } & \multirow[t]{2}{*}{ Question } & \multicolumn{2}{|c|}{ Correct } & \multicolumn{2}{|c|}{ Incorrect } \\
\hline & & Number & Percent & Number & Percent \\
\hline 1 & $\begin{array}{l}\text { Does HIV transmit through eating utensils with } \\
\text { someone who has AIDS? }\end{array}$ & 290 & 77.3 & 85 & 22.7 \\
\hline 2 & $\begin{array}{l}\text { Does HIV transmit through needles and syringes } \\
\text { used by someone else? }\end{array}$ & 303 & 80.8 & 72 & 19.2 \\
\hline 3 & $\begin{array}{l}\text { Does HIV transmit through the use of sharp tools and } \\
\text { tattooing needles that someone else has already used? }\end{array}$ & 73.9 & 277 & 98 & 26.1 \\
\hline 4 & $\begin{array}{l}\text { Does consistent condom use can prevent HIV } \\
\text { transmission in sexual relations? }\end{array}$ & 192 & 51.2 & 183 & 48.8 \\
\hline 5 & $\begin{array}{l}\text { Does HIV transmit through mother-to-child with } \\
\text { (son of the stomach)? }\end{array}$ & 216 & 57.6 & 159 & 42.4 \\
\hline 6 & Does HIV transmit through mosquito bites? & 140 & 37.3 & 235 & 62.7 \\
\hline 7 & $\begin{array}{l}\text { Does HIV transmit through sneezing, coughing } \\
\text { and saliva of people with the AIDS virus? }\end{array}$ & 229 & 61.1 & 146 & 38.9 \\
\hline 8 & $\begin{array}{l}\text { Does HIV transmit through kissing and hugging } \\
\text { and shaking hands with people with the AIDS virus? }\end{array}$ & 235 & 62.7 & 140 & 37.3 \\
\hline 9 & Whether for prevention of HIV, there is a vaccine? & 253 & 67.5 & 122 & 32.5 \\
\hline 10 & Is AIDS has any cure? & 229 & 61.1 & 146 & 38.9 \\
\hline 11 & $\begin{array}{l}\text { Anyone who regularly appears healthy may be } \\
\text { infected with AIDS? }\end{array}$ & 225 & 60 & 150 & 40 \\
\hline 12 & $\begin{array}{l}\text { Does the risk of HIV decrease through sex with not } \\
\text { HIV-infected people who do not have other sexual } \\
\text { partners? }\end{array}$ & 200 & 53.3 & 175 & 46.7 \\
\hline 13 & $\begin{array}{l}\text { Does HIV transmit through the knife used in } \\
\text { barbershops? }\end{array}$ & 263 & 70.1 & 112 & 29.9 \\
\hline 14 & $\begin{array}{l}\text { Does an AIDS transmit through the scissors used } \\
\text { in barbershops? }\end{array}$ & 111 & 29.6 & 264 & 70.4 \\
\hline 15 & Does HIV transmit through the hair used in hair? & 299 & 79.7 & 76 & 20.3 \\
\hline 16 & $\begin{array}{l}\text { Does HIV transmit through the comb and brush } \\
\text { used in hair? }\end{array}$ & 249 & 66.4 & 126 & 33.6 \\
\hline 17 & Does HIV transmit via the hairdresser to others? & 258 & 68.3 & 199 & 31.7 \\
\hline
\end{tabular}




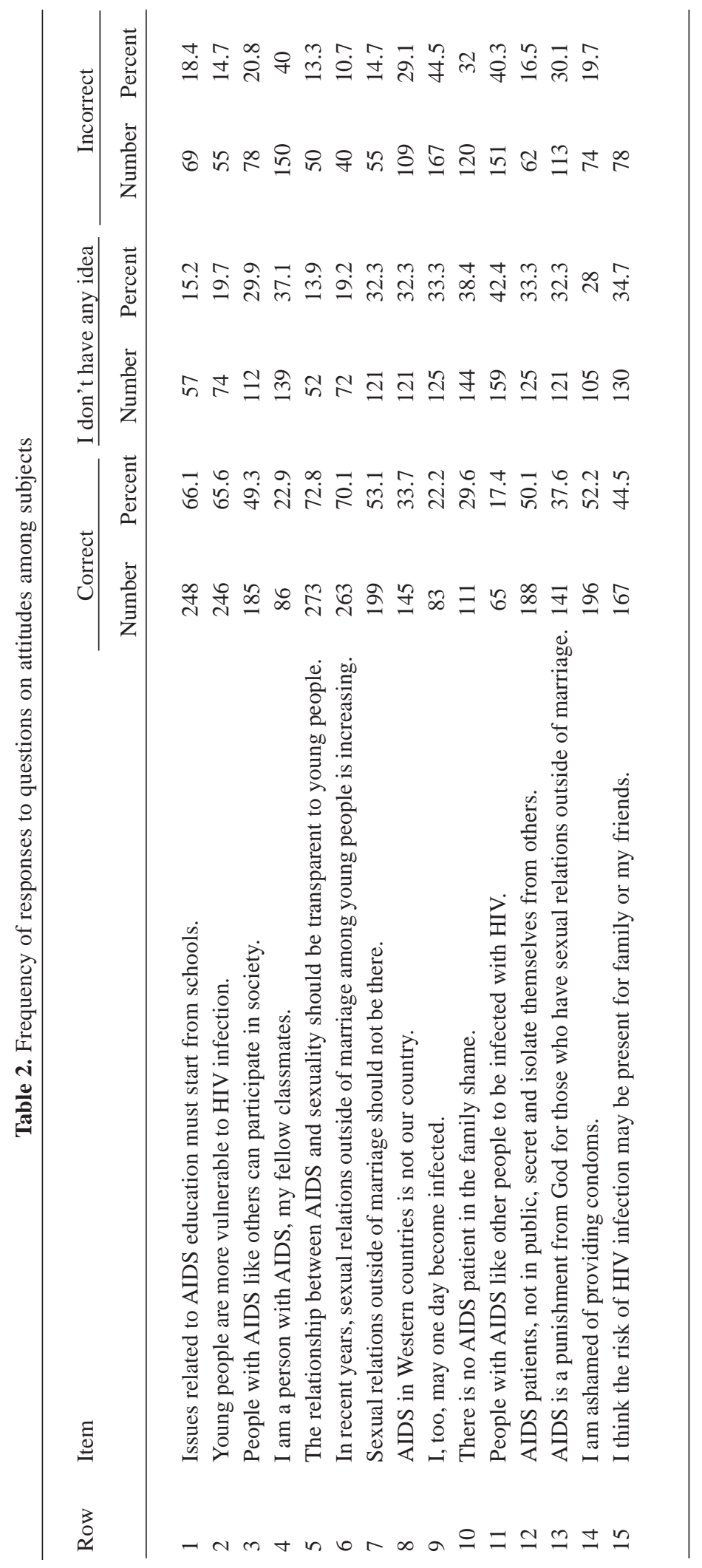


about AIDS prevention that carried on in Zanjan. Therefore, this study aimed to assess the knowledge and attitudes of male and female barbers in Zanjan in 2013 about AIDS and knowing more about designed the factors associated with it.

Kind of study

This study was a descriptive study. Study population: The population studied was all barbers working in the city.

According to the following formula and references: $\mathrm{P}=0.5 \mathrm{~d}=0.05 \alpha=0.05$

$$
n \frac{Z_{1 \frac{a}{2}}^{2}\left[p\left(\begin{array}{ll}
1 & p
\end{array}\right)\right]}{d^{2}}
$$

The sample was calculated 384 .

\section{Sampling}

The level of knowledge and attitude questionnaire:

The questionnaire includes 17 questions about demographic information as well as awareness of AIDS and 15 questions in relation to the attitude of barbers in the field of AIDS and its validity was confirmed by the respective professors and its reliability by test-retest $(\mathrm{r}=0.86)$ the control consciousness of a score was given to each correct answer the questions and those who answer the questions correctly were 75 percent above the good level, 50 to 75 percent of moderate and low level was defined as less than $50 \%$ in the attitude of the correct option 3, option 2 The idea and the wrong option was awarded 1 point and percentage of scores more than $80 \%$ completely positive attitude, percent attitude acceptable 60 to 80 percent between 40 and 60 percent attitude and scores below 40 were considered poor attitude. The questionnaire is attached.

\section{Procedure}

In this study, the spatial scale on the basis of scientific resources and disinfection prepared under the supervision of the barbers and distributed among 20 of them validity was assessed 0.86 that after the preparation of the questionnaire referred to the Union names Zanjan Barbers address all Barbers Zanjan prepared by the student is responsible for helping women to barber with 2 people, During July and August 2014 progressively and on the basis of random samples referred to salons and then to see comments questionnaires among the barbers who wish to participate in this study questionnaire distributed after the completion of the questionnaire collection and data mining software and SPSS and calculate the average percentage analysis and T-test and chi-square analyzed. Data analysis: Data obtained analyzed using SPSS software. For quantitative variables, determine the range, mean, standard deviation and other essential items P Value, extracted. The P Value considered with value less than or equal to 0.05 $(\mathrm{p} \leq 0.05)$.

Table 3. Mean and Standard deviationof knowledge among people in some of the variables among studied people

\begin{tabular}{|c|c|c|c|c|}
\hline Group & & Mean & $\begin{array}{l}\text { Standard } \\
\text { deviation }\end{array}$ & P-value \\
\hline \multirow{6}{*}{ Age } & Male & 57.5 & 27.9 & \multirow[t]{2}{*}{0.0001} \\
\hline & Female & 65.9 & 24.0 & \\
\hline & Less than 24 & 59.4 & 23.9 & \multirow[t]{6}{*}{0.075} \\
\hline & $24-32$ & 62.1 & 21.8 & \\
\hline & $32-40$ & 70.4 & 25.0 & \\
\hline & $40-48$ & 62.2 & 27.0 & \\
\hline \multirow{5}{*}{ Education } & $48-56$ & 51.5 & 30.1 & \\
\hline & Top 56 & 47.7 & 31.2 & \\
\hline & Illiterate & 28.8 & 34.7 & \multirow[t]{4}{*}{0.0001} \\
\hline & High school diploma & 45.5 & 28,3 & \\
\hline & Diploma & 68.8 & 19.7 & \\
\hline \multirow{3}{*}{ History of education } & Collegiate & 71.4 & 27.9 & \\
\hline & have & 71.6 & 21.2 & \multirow[t]{2}{*}{0.0001} \\
\hline & Not have & 52.0 & 27.1 & \\
\hline
\end{tabular}




\section{Findings}

In this study, 390 of hairdressers completed questionnaires that 15 of them excluded due to incomplete questionnaire and 375 questionnaires of them analyzed, of which 42.4 percent were male barbers and 57.6 percent were female barbers. The average age of men $34.85 \pm$ 9.47 years, the average age of women $33.80 \pm 9.28$ years and the mean age of the whole people studied were $34.25 \pm 9.36$ years. Among the questions to assess the level of awareness of questions relating to the transmission of HIV through needle with 80.8 percent most correct answer and then, questions 15 and 1 that the transmission of the virus through a hairdryer and eating in the 79.7 and 77.3 respectively common dishes percent were rows. In contrast had the lowest response to Question 14, 8 and 7, respectively, 26.9, 37.3 and 38.9 respectively of the correct answer. (Table 4-1)
Among the options the attitude, the "relationship between AIDS and sex issues should be transparent to the young people.” The correct answer was most 72.8 of the option "I may someday infect. "The 44.5 of the most incorrect answers (Table 2 - 4)

But, overall, $26.4 \%$ had of low level knowledge, $28.3 \%$ of moderate level of knowledge and 45.4 percent had good knowledge. In between the sexes also mean knowledge women $65.9 \pm 24.0$ and men $57.5 \pm 27.9$ was the difference between the two groups was statistically significant $(p=0.0001)$ among groups age $32-40$ years of age with the greatest knowledge of the average score $47.7 \pm 31.2$ and the lowest score for the aged above 56 years with an average score of $2 / 31 \pm 7 / 47$ was $(p=0.075)$ The average score of knowledge among people who were illiterate $7 / 34 \pm 8 / 38$ and the average score of those with a university education

Table 4. The mean and standard deviation score of attitude among some of the variables studied

\begin{tabular}{llccc}
\hline Group & & Mean & $\begin{array}{c}\text { Standard } \\
\text { deviation }\end{array}$ & P-value \\
\hline \multirow{4}{*}{ Age } & Male & 71.91 & 9.8 & 0.0001 \\
& Female & 75.27 & 10.0 & \\
& Less than 24 & 71.89 & 7.12 & 0.075 \\
& $24-32$ & 73.36 & 9.15 & \\
& $32-40$ & 76.02 & 10.43 & \\
40-48 & 74.83 & 9.71 & \\
Education & 48-56 & 70.47 & 11.57 & \\
& Top 56 & 69.30 & 13.20 & \multirow{2}{*}{0.0001} \\
& Illiterate & 67.66 & 6.82 & \\
& High school diploma & 65.62 & 10.84 & \\
History of education & Diploma & 76.94 & 7.95 & \\
& Collegiate & 77.61 & 8.64 & \multirow{2}{*}{0.0001} \\
& have & 77.27 & 7.9 & \\
\hline
\end{tabular}

had a $71.6 \pm 21.2$ was the difference between people with different educational levels was statistically significant $(\mathrm{p}=0.0001)$ Average score of knowledge in people who had AIDS education 71.6 \pm 21.2 and in those who had a history of training $52.2 \pm 27.1$ was $(\mathrm{P}=0.0001)$ (Table 3.4). Positive attitude is the attitude of 26.1, 62.1 and 11.7 percent of the acceptable attitude percent had moderate attitude of the average attitude of the participants $73.8 \pm$ 10.1 between the sexes in the mean attitude among women $75.2 \pm 10.0$ and among men $71.9 \pm 9$.8age groups, the highest scores were in the age range 32-40 years, as well as those who had a college education mean attitude higher than those with a lower education level (Table 4.4)

\section{DISCUSSION}

This study was a descriptive study that aimed to assess the knowledge and attitudes of Zanjan barbers towards HIV. The results of this study showed that less than half of the people 
who have good knowledge about a quarter of people with low level despite this level knowing that most people are relatively poor attitude was very positive and acceptable, contrary to the findings of our study $76 \%$ of Mahmoud Karimi good knowledge and $49 \%$ of the samples had a good attitude ${ }^{13}$ or that in another study by Mahmud as knowledge, attitude and practice of the barber was aimed at AIDS prevention in 50\% and $48.43 \%$ of them had good knowledge and 43.4 percent average yield poor attitude in this study were between knowledge and attitude, attitude and practice with regard to experience significant relationship was observed ${ }^{14}$. The difference in results may be due to differences in knowledge assessment tool, sample size and the economic and cultural issues. In this study, parsley and colleagues barber's awareness about the prevention and control of AIDS, the 8.98\% were good, while about $4.36 \%$ of them had wrong information and attitude ${ }^{51}$. In our study, knowledge and attitude of women to better than men do, which is in line with the parsley and colleagues ${ }^{51}$. In our study who had attended training classes, Knowledge and attitude had better control of disease prevention. In this study, it was found that education about diseases transmitted hairdressers hairdresser correction needs to expand, which in the area of health care workers have an important role. And those who also had a history of previous education on AIDS knowledge and attitudes were more favorable effect of education on knowledge and attitude of barbers in the study were included in the study for the Bichari and colleagues that the impact of education on knowledge and attitude of Barbers Birjand on AIDS took place, in this study, the training sessions of 10 to 15 people in the class were provided in health centers, the results showed that education on awareness and attitudes Barbers Birjand had a great impact ${ }^{52}$.In the present study it was observed that the level of education significantly AIDS awareness and attitudes towards that this result is expected respectively. Among the age group 32-40 years age group with the greatest knowledge of the average score and the lowest score was in the age range of 56 years, with an average score. From these findings it can be concluded that in this age range, according to which the people are at risk At the same time experience Working in a variety of ways given the necessary information on AIDS and older than it is due to this that are not so prone to AIDS Less information than others and younger people with less work experience, The opportunity to acquire the necessary information has not been obtained. Suggestions: The results of this study showed that knowledge of the subjects at relatively low levels, and among less educated people, men and those who have no history of educational Know less and therefore should be considered more targeted training programs but the attitude of most people is desirable propose In future studies, in addition to knowledge, attitude and practice regarding preventive measures attitudes and awareness of AIDS and also to evaluate the performance of the as well as training programs for raising awareness beauticians and especially those in the study had low awareness level.

\section{Ethical considerations}

1. The approval of the Ethics Committee of Research Department of Zanjan University of Medical Sciences and Health Services.

2. Obtaining written informed consent and legal patients for the study.

3. Confidentiality of participant's information

4. Official permission from the hospital authorities

5. Provide an overview of results to patients and nurses

6. Privacy of participants.

\section{ACKNOWLEDGMENTS}

In collaboration with the University of Medical Sciences in Zanjan which funded the costs of the project.

\section{REFERENCES}

1. Jerald-Bennett john-Dolin—principle\& practice of infectious disease. Fourth edition- Churchill livingstone- 2010.

2. Kasper dennis . Longo D.E. Fauci A. Harrisons principles of Internal medicine. The McGrawHill Companies, Inc. 18th edition. 2012 .

3. Andreoli. Carpenter.Griggs.Loscalzo .Cecil essential of medicine.6th.2004

4. Zarban, Hidarnia A, Rakhshani F. et al. The efficacy of HIV prevention education on knowledge and practice of seamen Chah Bahar, Doctor East Quarterly, 2006; 34: 8-29 
5. Vakili, mm. Knowledge and attitudes of men addicted to the central prison of AIDS in Zanjan, Zanjan University of Medical Sciences Summer 1998; 5:17 -23.

7. Gashtasby Vahdani Sadat mm,RezaiN Awareness of Married women in urban areas of Boyer-Ahmad about AIDS. Knowledge brings Journal 2006; 6: 99-105 8

8. Nojoumi M, Shojaei H, Amerian MA. [Knowledge of high school students about AIDS Tehran 2002 . Hakim 2003; 6(3):41-46.(Persian)

9. Poorsheykhian M, Kazemnejad E. A study on knowledge and attitude of clinical laboratoriespersonnel about AIDS in Gilan. Feyz J 2004; 8(1): 66-72 [in Persian].

10. Mohebi Nobandegani Z, Mobaraki A, AfrasiabiFar A, Moshfe AA. Knowledge and attitude of health personnels working in educationaltreatment hospitals-Yasuj city regarding AIDS. Armaghane Danesh J 2003; 8(30): 47- 54. [In Persian]

11. Pakfetrat A, Shahabi Nezhad H.A study on general knowledge of the patients referring to Mashhad Dental School about AIDS. J Mashhad Dental School 2005; 28(3,4): 141-50. [In Persian].

12. Pruss-ustun A, Rapiti E, Hutin Y. Estimation of the global burden of disease attributable to contaminated sharps injuries among health-care workers. Am J Ind Med 2005; 48:482-90.

13. Uneke CJ, Alo M, Ogbu O. Mandatory premarital HIV testing in Nigeria: The public health and social implications. AIDS Care. 2007; 19(1):116-21.

14. Akani CI, Erhabor O, Babatunde S. Premarital HIV testing in couples from faith-based organizations: experience in Port Harcourt, Nigeria. Niger J Med. 2005;14(1):39-44]

15. Surur F. The role of religious leaders in HIV/ AIDS prevention.control and patient care and support: A pilot project in Jimma zone. Northeast African Studies. 2000; 7(2):59-79.

16. Ragab ARA, Mahmoud M, Serour GI. Mobilizing religiousleaders to join fight against HIV/AIDS: Results of a qualitative research from Egypt.Sexuality in Africa. 2006; 3(3).

17. Genrich GL, Braithwaite BA. Response of religious groups to HIV/AIDS as a sexually transmitted infection in Trinidad. BMC Public Health. 2005; 5: 121.

18. Umeora OU, Esike C. Prevalence of HIV infection among premarital couples in Southeast Nigeria. African Journal of AIDS Research. 2005; 4(2): 99-102.

19. Luginaah IN, Yiridoe EK, Taabazuing MM. From mandatory to voluntary testing; balancing human rights, religions and cultural values, and HIV/ AIDS prevention in Ghana. SocSci Med. 2005; 61(8):1689-700.

20. Zafar T, Hasan S. A sociodemographic and behavioral profile of heroin users and the risk environment in Quetta, Pakistan. Int J Drug Policy. 2002;13:121-125. doi: 10.1016/S09553959(02)00011-7.

21. Strathdee SA, Zafar T, Brahmbhatt H, et al. Higher level of needle sharing among injection drug users in Lahore, Pakistan, in the aftermath of the US-Afghan war. Paper presented at: Fourteenth International Conference on AIDS; July 7-12, 2002; Barcelona, Spain. Abstract MoPpC2018.

22. Poshyachinda V. Drug injecting and HIV infection among the population of drug abusers in Asia. Bull Narc. 1993;45:77-90.

23. Weniger BG, Brown T. The march of AIDS through Asia. N Engl J Med. 1996; 335: 343345. doi: 10.1056/NEJM199608013350510.

24. Khanani RM, Hafeez A, Rab SM, et al. Human immunodeficiency virus-associated disorders in Pakistan. AIDS Res Hum Retroviruses. 1988; 4: 149-154.

25. Mujeeb SA, Hashmi MRA. A study of HIVantibody sera of blood donors and people at risk. J Pak Med Assoc. 1998;38:221-222.

26. Khan OA, Hyder AA. Responses to an emerging threat: HIV/AIDS policy in Pakistan. Health Policy Plann. 2001;16:214-218. doi: 10.1093/ heapol/16.2.214.

27. Hyder AA, Khan OA. HIV/AIDS in Pakistan: the context and magnitude of an emerging threat. J Epidemiol Community Health. 1998; 52: 579585

28. Kazi BM, Ghaffar A, Salman M. Health care systems in transition III. Pakistan, Part II. Pakistan's response to HIV-AIDS. J Public Health Med. 2000; 22: 43-47.

29. Ali S, Khanani R, Tariq WU. Understanding the context of HIV/AIDS infection in Pakistan. Venerology. 1995; 8: 160-163.

30. Lynn W. Pakistan launches media blitz on AIDS. Global AIDS News. 1994; 2: 1-2.

30. Zafar T, Brahmbhatt H, Imam G, ul Hassan S, Strathdee SA. HIV knowledge and risk behaviors among Pakistani and Afghani drug users in Quetta, Pakistan. J Acquir Immune DeficSyndr. 2003; 32: 394-398.

31. Hankins CA, Friedman SR, Zafar T, Strathdee SA. Transmission and prevention of HIV and STD in war settings: implications for current and future armed conflicts. AIDS. 2002; 16: 2245-2252. .

32. Luby SP, Khanani R, Zia M, et al. Evaluation of 
blood bank practices in Karachi, Pakistan, and the government's response. Health Policy Plann. 2000;15:217-222.

33. Luby SP, Niaz Q, Siddiqui S, et al. Patients' perceptions of blood transfusion risks in Karachi, Pakistan. Int J Infect Dis. 2001; 5: 24 26.

34. Lau JT, Thomas J, Lin CK. HIV related behaviours among voluntary blood donors in Hong Kong. AIDS Care. 2002;14:481-492

35. Panda S, Chatterjee A, Battacharya SK, et al. Transmission of HIV from injecting drug users to their wives in India. Int J STD AIDS. 2000; 11: 468-473.

37. Yamamoto JK, Sparger E, Ho EW, Andersen PR, O’Connor TP, Mandell CP, Lowenstine L, Munn R, Pedersen NC. Pathogenesis of experimentally induced feline immunodeficiency virus infection in cats. Am $J$ Vet Res. 1988; 10: 1246-1258.

38. Kohmoto M, Uetsuka K, Ikeda Y, Inoshima Y, Shimojima M, Sato E, Inada G, Toyosaki T, Miyazawa T, Doi K, Mikami T. Eight-year observation and comparative study of specific pathogen-free cats experimentally infected with feline immunodeficiency virus (FIV) subtypes $\mathrm{A}$ and $\mathrm{B}$ : terminal acquired immunodeficiency syndrome in a cat infected with FIV petaluma strain. J Vet Med Sci. 1998;10:315-321.

39. Ackley CD, Yamamoto JK, Levy N, Pedersen NC, Cooper MD. Immunologic abnormalities in pathogen-free cats experimentally infected with feline immunodeficiency virus. $J$ Virol. 1990; 10: 5652-5655.

40. Barlough JE, Ackley CD, George JW, Levy N, Acevedo R, Moore PF, Rideout BA, Cooper MD, Pedersen NC. Acquired immune dysfunction in cats with experimentally induced feline immunodeficiency virus infection: comparison of short-term and long-term infections. J Acquir Immune DeficSyndr. 1991; 10: 219-227.

41. Gemeniano MC, Sawai ET, Leutenegger CM, Sparger EE. Feline immunodeficiency virus ORF-Ais required for virus particle formation and virus infectivity. J Virol. 2003;10:88198830

42. Gemeniano MC, Sawai ET, Sparger EE. Feline immunodeficiency virus Orf-A localizes to the nucleus and induces cell cycle arrest. Virology. 2004;10:167-174.

43. Chatterji U, de Parseval A, Elder JH. Feline immunodeficiency virus OrfA is distinct from other lentivirustransactivators. J Virol. 2002; 10: 9624-9634.
44. Dean GA, Reubel GH, Moore PF, Pedersen NC. Proviral burden and infection kinetics of feline immunodeficiency virus in lymphocyte subsets of blood and lymph node.J Virol. 1996;10:51655169.

45. Gulzar N, Copeland KF. CD8+ T-cells: function and response to HIV infection. Curr HIV Res. 2004; 10: 23-37.

46. Embretson J, Zupancic M, Beneke J, Till M, Wolinsky S, Ribas JL, Burke A, Haase AT. Analysis of human immunodeficiency virusinfected tissues by amplification and in situ hybridization reveals latent and permissive infections at single-cell resolution. Proc Natl Acad Sci USA. 1993;10:357-361

47. English RV, Johnson CM, Gebhard DH, Tompkins MB. In vivo lymphocyte tropism of feline immunodeficiency virus. J Virol. 1993; 10: $5175-5186$.

48. Fritsch L, Marechal V, Schneider V, Barthet C, Rozenbaum W, Moisan-Coppey M, Coppey J, Nicolas JC. Production of HIV-1 by human B cells infected in vitro: characterization of an EBV genome-negative $\mathrm{B}$ cell line chronically synthetizing a low level of HIV-1 after infection. Virology. 1998; 10: 542-551

49. Mahmoud. Health Belief Model on knowledge, attitude and behavior towards the disease Barbers ZarandiehAydz. National Conference of Environmental Health, 2009.

50. Mahmoud Sh, Hosseini, knowledge, attitude and practice on AIDS prevention barbers in Gorgan University of Medical Sciences Journal, 2000; 2(1): 26-32

51. Jaffery, Considering the level of awareness, kind of attitude and practice about AIDS Branch barbers in Eslamshahr. Tehran University of Medical Sciences site.http://publicrelations. tums.ac.ir/news/detail.asp?newsID=790

52. Bijari B, Abassi A, SharifzadeGh.R, Salehi S. Effects of Health Education Program on Knowledge and Attitude of Barbers and Beauticians in Birjand about AIDS. J Rafsanjan Univ Med Scie 2012; 11(5): 489-94.

53 Ghanepour M. R., Hamedi V., Parimi F. KAP Study of Woman Hairdressers about Hygiene and Infetious Diseases in Damghan City. feyz , 1385; 33:23-31.

54. cAfsari Kazerouni, Heidari, M. Amini Lari, MSayadi M Sabet. Investigation on knowledge and attitude of nurses and auxiliary nurses in Shiraz Faculty of Nursing .Magazine of Hamedan 2010; 18(2): 28-32. 